\title{
HUBUNGAN ANTARA KETEKUNAN (PERSISTENCE) DENGAN HASIL BELAJAR BIOLOGI: STUDI KORELASIONAL TERHADAP SISWA KELAS X MIA DI SMA NEGERI 102 JAKARTA
}

\author{
The Relationship between Persistence with Biology \\ Learning Outcomes: Correlational Study Toward Student of \\ Sains Grade X at 102 Senior High School of Jakarta \\ Mieke Miarsyah, I Made Putrawan, Dea Hermadianti \\ Pendidikan Biologi Fakultas MIPA Universitas Negeri Jakarta \\ Email: mmiarsyah@unj.ac.id
}

\begin{abstract}
Persistence refers to the length of time a person sticks with a given action. This can be seen from staying power of behavior or how long a person will continue to devote effort. The purpose of this research was to determained the relationship between persistence with biology learning outcomes of students of Sains grade X on ecosystem material. The research was accomplished at 102 Senior High School of Jakarta in April-May 2016. The method of this research used survey method through correlational study. The subject of this research were students of Sains grade $X$ with sample of 75 students were selected by simple random sampling. Results of the normality data tested by Kolmogorov Smirnov test, resulting that two data population normality distributed. Data homogenity tested by Bartlett test resulting data obtained from the two homogeneous variable. Hypothesis test using regression test, found that the regression model $\hat{Y}=2.547+0.208 \mathrm{X}$ had a significant and linier relationship. The result of Pearson Product Moment test was correlation value obtained 0.87 . The calculation of the determination coefficient obtained 0.7569 . It was that $75.69 \%$ of persistence contributed to the biology learning outcomes on ecosystem material while $24.31 \%$ was determined by other factors.
\end{abstract}

\section{Keywords : Persistence, biology learning outcomes, ecosystem}

\section{PENDAHULUAN}

Ketekunan (persistence) merujuk pada kuantitas waktu yang dihabiskan oleh individu dalam menuntaskan pekerjaannya (Schermerhorn, et.al., 2011).

Hasil belajar merupakan suatu perubahan berupa perubahan tingkah laku, pengetahuan, dan sikap yang diperoleh seseorang setelah melakukan proses kegiatan belajar (Dimyati dan Mudjiono, 2006). Hasil belajar ranah kognitif merupakan ranah yang paling dinilai oleh guru di sekolah karena berkaitan dengan kemampuan siswa dalam menguasai isi bahan pengajaran (Sudjana, 2012).

Ekosistem adalah satuan yang mencakup semua organisme (yakni komunitas) di dalam suatu daerah yang saling mempengaruhi dengan lingkungan fisiknya sehingga arus energi mengarah ke struktur makanan pada keanekaragaman biotik dan daur-daur bahan yang jelas (yakni pertukaran bahan- 
bahan antara bagian-bagian yang hidup dan tidak hidup) di dalam sistem (Odum, 1993).

Berdasarkan data yang diperoleh dari guru bidang studi biologi di SMA Negeri 102 Jakarta, bahwa hasil belajar ekosistem dari ketiga kelas X MIA pada tahun pelajaran 2014/2015 masih di bawah KKM, yaitu 75. Terdapat 66 siswa atau $61 \%$ siswa yang belum mencapai nilai KKM dan 42 siswa atau 39\% siswa yang sudah mencapai KKM dari jumlah siswa kelas X MIA sebanyak 108 siswa.

Menurut hasil wawancara dengan guru bidang studi biologi, hal tersebut terjadi karena siswa cukup banyak dibebankan oleh tugas sehingga menuntut siswa untuk fokus mengerjakan tugas tersebut sampai selesai tanpa mengenal lelah. Berdasarkan hasil observasi terhadap siswa, terlihat bahwa siswa yang kurang mampu mengerjakan tugas-tugas sampai selesai, umumnya dikarenakan siswa tersebut menunda-nunda dalam mengerjakan tugas. Bahkan merasa putus asa dan tidak mau mengerjakan tugas-tugasnya lagi. Hal ini berdampak pada nilai ulangan beberapa siswa yang kurang memuaskan atau dibawah Kriteria Ketuntasan Minimal (KKM). Salah satu faktor yang mempengaruhi hal tersebut adalah motivasi, dalam hal ini ketekunan (persistence), karena ketekunan (persistence) merupakan komponen penting dari motivasi (Ivancevich, et.al., 2007).

Oleh karena itu, atas dasar pemikiran tersebut diduga terdapat hubungan yang positif antara ketekunan (persistence) dengan hasil belajar biologi siswa.

\section{METODE}

Metode penelitian yang digunakan adalah metode survei melalui studi korelasional. Variabel bebas (X) pada penelitian ini adalah ketekunan (persistence), sedangkan variabel terikat (Y) adalah hasil belajar biologi siswa.

\section{TEMPAT DAN WAKTU PENELITIAN}

Penelitian ini dilaksanakan di SMA Negeri 102 Jakarta, pada bulan April Mei 2016.

\section{SAMPEL PENELITIAN}

Sampel yang digunakan pada penelitian ini adalah 75 siswa kelas X MIA SMAN 102 Jakarta yang ditentukan dengan cara simple random sampling.

\section{PROSEDUR ANALISIS DATA}

Teknik analisis data yang digunakan dalam penelitian ini adalah uji prasyarat analisis data meliputi uji normalitas dan uji homogenitas. Uji normalitas data dilakukan dengan menggunakan uji Kolmogorov-Smirnov pada $\alpha=0,05$, sedangkan uji homogenitas dihitung dengan menggunakan uji Bartlett pada $\alpha=$ 0,05. Uji hipotesis dilakukan melalui pengujian regresi linier dan korelasi sederhana. Regresi dan korelasi diuji dengan uji-F dan uji-t melalui ANAVA. Untuk menguji regresi dan linieritas, koefisien korelasi dihitung dengan Perason Product Moment pada $\alpha=0,05$. Apabila bentuk hubungan linier akan dihitung dengan koefisien determinan untuk menyatakan besar kecilnya kontribusi variabel $\mathrm{X}$ terhadap Y.

\section{HASIL DAN PEMBAHASAN}




\section{Hasil}

Berdasarkan perhitungan skor ketekunan (persistence) diperoleh kategori skor ketekunan (persistence) siswa. Pada Gambar 1 dapat dilihat diagram lingkaran kategori skor ketekunan (persistence). Diketahui sebanyak 55\% siswa (41 siswa) memiliki tingkat ketekunan (persistence) yang tinggi, sedangkan sebanyak 45\% siswa (34 siswa) memiliki tingkat ketekunan (persistence) sedang. Adapun siswa dengan tingkat ketekunan (persistence) rendah tidak ditemukan.
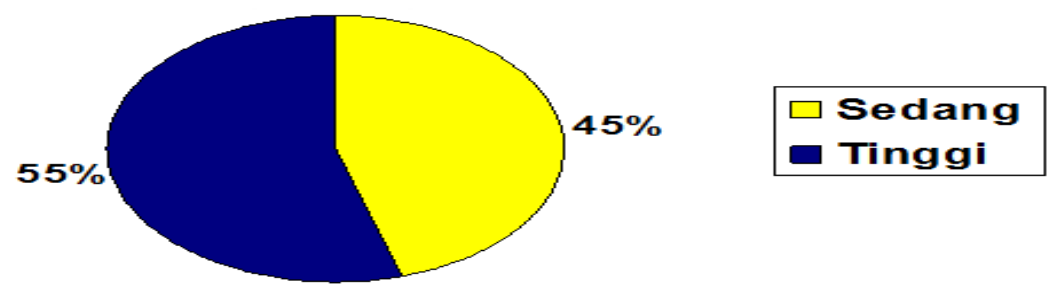

Gambar 1. Diagram Lingkaran Kategori Skor Ketekunan (Persistence)

Skor ketekunan (persistence) juga digambarkan berdasarkan delapan indikator. Perolehan nilai setiap indikator dapat dilihat pada Gambar 2.

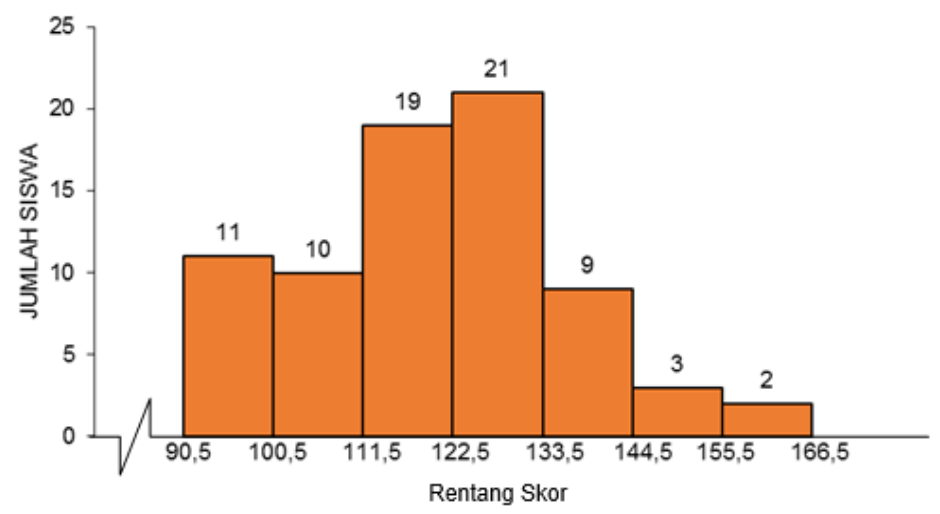

Gambar 2. Kontribusi Skor Ketekunan (persistence)

Pada data ketekunan (persistence) siswa didapat skor tertinggi 162 dan skor terendah 90. Rata-rata skor ketekunan (persistence) siswa adalah 120,55, variansi sebesar 253,39, dan simpangan baku sebesar 15,92.

Jumlah siswa terbanyak pada skor ketekunan (persistence) berada pada rentang skor 123-133 yaitu sebanyak 21 siswa dengan persentase sebesar $28 \%$. Jumlah siswa paling sedikit berada pada rentang skor 156-166 yaitu sebanyak 2 siswa dengan persentase sebesar 3\%. Pada Gambar 4 dapat dilihat distribusi frekuensi skor ketekunan (persistence). 


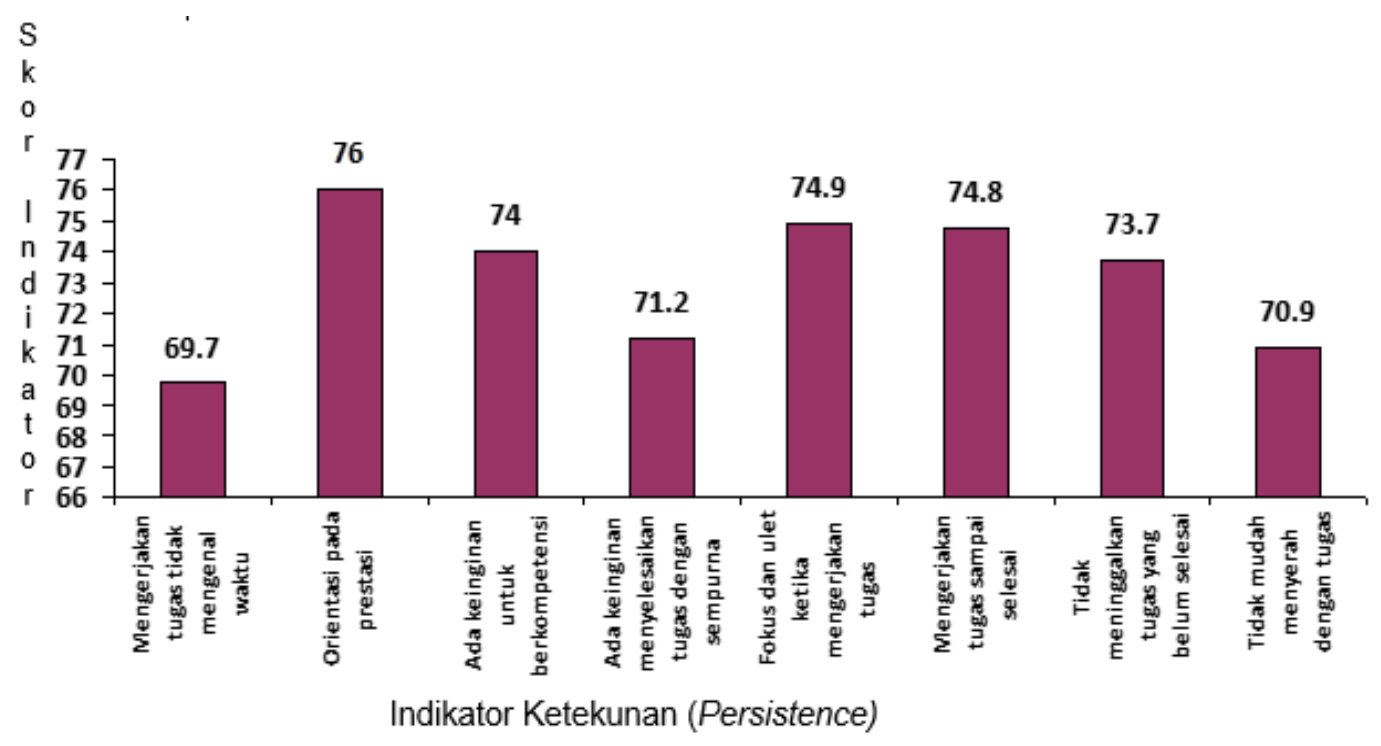

Gambar 3. Distribusi Frekuensi Skor Ketekunan (Persistence)

Berdasarkan perhitungan skor hasil belajar biologi, diperoleh skor kategori hasil belajar biologi. Pada Gambar 4 dapat dilihat diagram lingkaran kategori skor hasil belajar biologi.
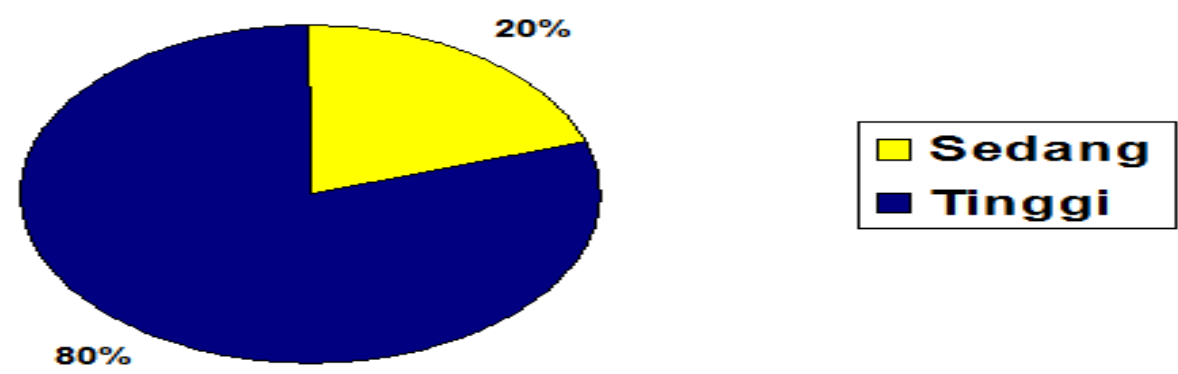

Gambar 4. Diagram Lingkaran Kategori Skor Hasil Belajar Biologi

Dari Gambar 4 dapat diketahui sebanyak $80 \%$ siswa (60 siswa) memiliki skor hasil belajar dengan kategori tinggi. Sedangkan sebanyak $20 \%$ (15 siswa) memiliki skor hasil belajar dengan kategori sedang. Adapun siswa yang memiliki skor hasil belajar dengan kategori rendah tidak ditemukan.

Pada data hasil belajar biologi didapat skor tertinggi 34 dan skor terendah 22. Rata-rata skor hasil belajar biologi adalah 27,72, variansi sebesar 14,56 , dan simpangan baku sebesar 3,82.

Jumlah siswa terbanyak pada skor hasil belajar biologi berada pada rentang skor 22-23 sebanyak 15 siswa dengan persentase sebesar $20 \%$. Jumlah siswa paling sedikit berada pada rentang skor 34-35 sebanyak 5 siswa dengan persentase sebesar 7\%. Pada Gambar 6 dapat dilihat distribusi frekuensi skor hasil belajar biologi. 


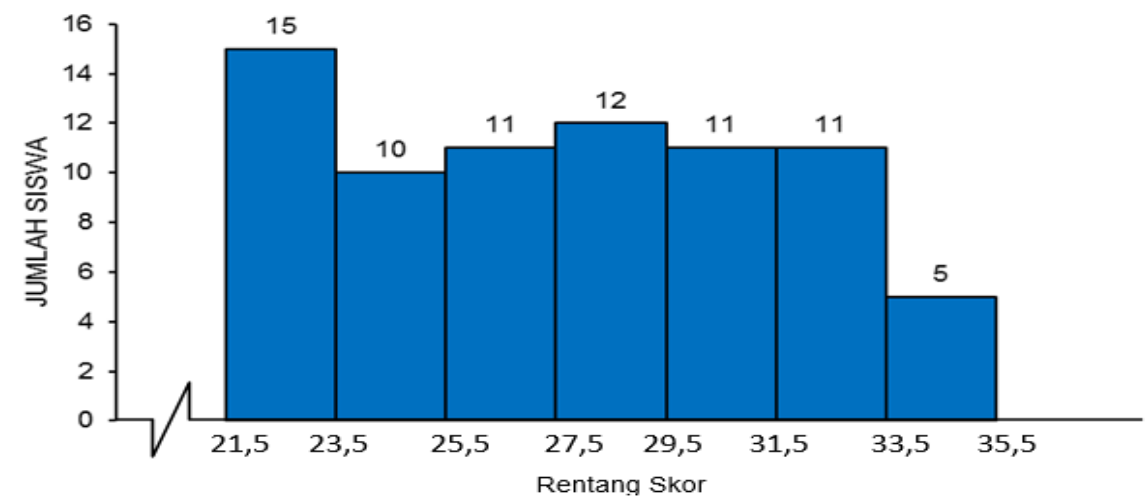

Gambar 5. Distribusi Frekuensi Skor Hasil Belajar Biologi

Pengujian normalitas dilakukan dengan menggunakan uji KolmogorovSmirnov pada $\alpha=0,05$. Data yang diuji adalah nilai galat taksiran, selisih $Y-\hat{Y}$. Setelah mendapat persamaan regresi $\hat{Y}=a+b X$ kemudian memasukkan skor $X$ setiap sampel, maka diperoleh $\hat{Y}$ setiap sampel. $\hat{Y}$ kemudian digunakan untuk mengurangi Y skor mentah.

Berdasarkan hasil perhitungan, diperoleh skor $\mathrm{Dh}_{\text {maks }}$ sebesar 0,065. Skor $\mathrm{Dh}_{\text {maks }}$ lebih kecil dari skor $\mathrm{D}_{\text {tabel }}$ yaitu 0,157 , maka terima $\mathrm{H}_{0}$ pada $\alpha=0,05$ yang artinya data ketekunan (persistence) dan hasil belajar biologi berasal dari populasi berdistribusi normal.

Pengujian homogenitas dilakukan dengan menggunakan uji Bartlett pada $\alpha$ $=0,05$. Berdasarkan hasil perhitungan diperoleh $\chi^{2}$ hitung sebesar 4,921 lebih kecil dari $X_{\text {tabel }}^{2}$ yaitu 48,6, maka terima $\mathrm{H}_{0}$ pada $\alpha=0,05$. Data yang homogen menunjukkan bahwa data kelompok-kelompok $\mathrm{Y}$ pada $\mathrm{X}$ tertentu memiliki homogenitas.

Model regresi linier yang diperoleh $\hat{Y}=2,547+0,208 X$. Dari hasil pengujian model regresi diperoleh $F_{\text {hitung }}$ lebih besar dari $F_{\text {tabel }}$ yakni 226,353 lebih besar dari 7,00 pada $\alpha=0,01$. Dengan demikian model regresi $\hat{Y}=2,547+$ $0,208 \mathrm{X}$ signifikan pada $\alpha=0,01$. Pada pengujian linieritas diperoleh $\mathrm{F}_{\text {hitung }}$ lebih kecil dari $F_{\text {tabel }}$ yakni 0,849 lebih kecil dari 2,22 pada $\alpha=0,01$, maka bentuk hubungan adalah linier pada $\alpha=0,01$.

\begin{tabular}{ccccccc}
\hline $\begin{array}{c}\text { Sumber } \\
\text { Varians }\end{array}$ & $\mathbf{k}$ & JK & RJK & $\mathbf{F}_{\text {hitung }}$ & $\begin{array}{r}\alpha= \\
0,05\end{array}$ & $\begin{array}{r}\mathbf{F}_{\text {tabel }} \\
0,01\end{array}$ \\
\hline Total (T) & 5 & 58707 & 58707 & & & \\
\hline $\begin{array}{c}\text { Regresi } \\
\text { (a) }\end{array}$ & & 57629,88 & 57629,88 & & & \\
\hline $\begin{array}{c}\text { Regresi } \\
\text { (b/a) }\end{array}$ & 814,419 & 814,419 & $226,353^{* *}$ & 3,97 & 7,00 \\
\hline Sisa (S) & 3 & 262,701 & 3,598 & & & \\
\hline Oocok (TC) & 9 & 10240,129 & 262,567 & $0,849^{\text {ns }}$ & 1,75 & 2,22 \\
\hline $\begin{array}{c}\text { Galat } \\
\text { (Error) }\end{array}$ & 4 & 10502,83 & 308,906 & & & \\
\hline
\end{tabular}


Tabel 1. Analisis Varians Regresi Linier Sederhana Model Regresi

$$
\hat{Y}=2,547+0,208 X
$$

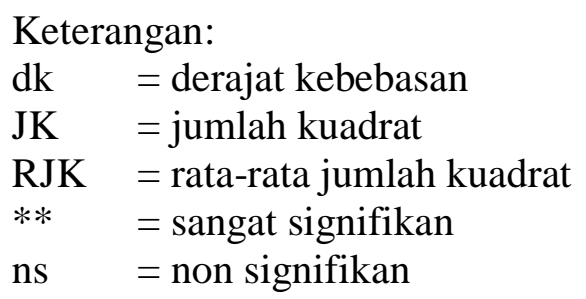

Diagram berikut menggambarkan hubungan antara ketekunan (persistence) dengan hasil belajar biologi.

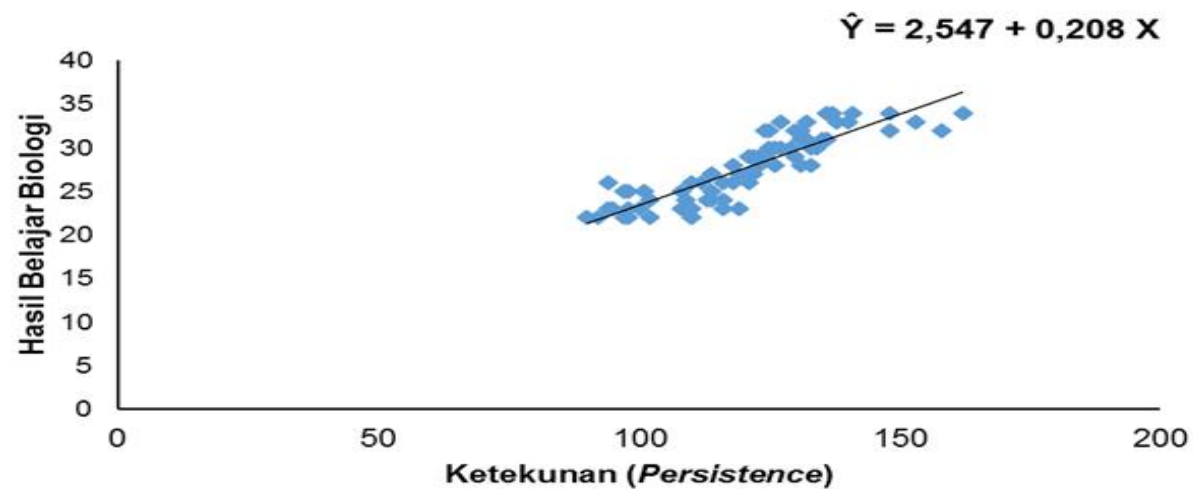

Gambar 6. Model Regresi Linier antara Ketekunan (Persistence) dengan Hasil Belajar Biologi

Pengujian prasyarat menunjukkan bahwa data normal dan homogen. Oleh karena itu, pengujian korelasi menggunakan rumus Pearson Product Moment. Berdasarkan hasil perhitungan, diperoleh koefisien korelasi $\left(\mathrm{r}_{\mathrm{xy}}\right)$ sebesar 0,87. Berdasarkan koefisien korelasi $\left(\mathrm{r}_{\mathrm{xy}}\right)$, hasil $\mathrm{t}_{\text {hitung }}>\mathrm{t}_{\text {tabel }}$ yaitu 15,07 $>2,032$ pada $\alpha$ $=0,05$. Hal ini menunjukkan koefisien korelasi signifikan dan terdapat hubungan positif antara ketekunan (persistence) dengan hasil belajar biologi.

Perhitungan koefisien determinasi dilakukan untuk mengetahui besarnya kontribusi variabel $\mathrm{X}$ terhadap variabel $\mathrm{Y}$. Koefisien determinasi diperoleh sebesar 0,7569. Hal ini berarti sebesar 75,69\% variabel ketekunan (persistence) memberikan kontribusi terhadap hasil belajar biologi siswa pada materi ekosistem. Sedangkan $24,31 \%$ disebabkan oleh faktor lainnya.

\section{PEMBAHASAN}

Hasil penelitian menunjukkan bahwa terdapat hubungan positif antara ketekunan (persistence) dengan hasil belajar biologi. Koefisien korelasi yang diperoleh pada penelitian ini sebesar 0,87 yang signifikan pada $\alpha=0,05$. Ketekunan (persistence) memberikan kontribusi terhadap hasil belajar sehingga memiliki hubungan yang positif. Berdasarkan hasil penelitian, dari data 75 sampel yang diambil melalui kuesioner didapatkan 45\% (34 siswa) memiliki tingkat ketekunan (persistence) sedang dan sebesar 55\% (41 siswa) memiliki tingkat ketekunan (persistence) yang tinggi. Hal ini berkaitan dengan penelitian yang menyatakan bahwa semakin tinggi jenjang pendidikan, maka seseorang akan 
memiliki ketekunan yang tinggi, selain itu hasil belajar yang baik juga sangat berhubungan dengan ketekunan. (Ishler, Jennifer L.Crissman dan M. Lee Upcraft). Dalam hal ini, siswa yang memiliki tingkat ketekunan (persistence) yang tinggi akan mengarah pada pencapaian yang baik, salah satu pencapaian tersebut adalah hasil belajar.

Secara teoritis, ketekunan (persistence) merujuk pada kuantitas waktu yang dihabiskan oleh individu dalam menuntaskan pekerjaannya (Schermerhorn, et.al., 2011). Individu dengan ketekunan (persistence) yang tinggi akan menyelesaikan tugas tepat waktu dan meningkatkan kemampuannya agar mendapat hasil yang baik dalam hal ini hasil belajar. Hubungan ketekunan (persistence) dengan hasil belajar didasarkan bahwa individu cenderung memiliki komitmen yang tinggi untuk mendapatkan hasil yang baik dan fokus dalam menuntaskan pekerjaannya.

Ketekunan (persistence) adalah keinginan individu untuk sukses dan berhasil dalam segala hal melalui kegiatan-kegiatan yang bersifat fokus dan penuh konsentrasi serta diikuti oleh ketekunan dalam membangkitkan motivasi sehingga mampu memuaskan apa yang diinginkan. Pada instrumen ketekunan (persistence) terdapat 8 indikator. Berdasarkan persentase skor indikator, orientasi pada prestasi merupakan indikator yang memiliki kontribusi tertinggi yaitu sebesar 76,0 \%. Hal ini tentunya memperlihatkan bahwa siswa yang memiliki orientasi pada prestasi berkeinginan untuk mendapatkan hasil yang baik. Seperti yang diperlihatkan oleh siswa yang mempertahankan besar usahanya saat menyelesaikan pekerjaan dan tidak mudah menyerah dengan cepat untuk mendapatkan hasil yang memuaskan. Hal ini juga berkaitan dengan hasil penelitian yang menyatakan bahwa kualitas usaha siswa mempengaruhi tingkat belajar siswa dan dapat memberikan efek secara langsung pada ketekunan (Ishler, Jennifer L.Crissman dan M. Lee Upcraft).

Pada indikator mengerjakan tugas tidak mengenal waktu memiliki kontribusi terendah dengan persentase skor indikator sebesar 69,7 \%. Hal ini diperlihatkan oleh siswa yang tidak memanfaatkan waktunya untuk mengerjakan tugas sampai selesai. Keinginan untuk berkompetensi memiliki persentase skor indikator sebesar 73,4 \%. Berdasarkan data yang diperoleh, skor rata-rata hasil belajar biologi siswa sebesar 27,72. Hal ini mencerminkan bahwa kemampuan kognitif siswa tergolong tinggi. Berdasarkan skor yang diperoleh oleh siswa, menunjukkan bahwa siswa tersebut memiliki kompetensi pada materi yang telah dipelajari.

Pada indikator berikutnya yaitu keinginan menyelesaikan tugas dengan sempurna didapatkan persentase skor indikator sebesar $71,2 \%$. Hal ini diperlihatkan oleh siswa yang lebih teliti dalam menyelesaikan setiap tugas. Fokus dan ulet ketika mengerjakan tugas merupakan indikator yang memiliki persentase skor indikator sebesar 74,9\%. Hal ini diperlihatkan oleh siswa yang tidak mudah terganggu ketika mengerjakan tugas dan menyelesaikan tugas tepat waktu.

Mengerjakan tugas sampai selesai merupakan indikator dengan persentase skor indikator sebesar $74,8 \%$. Seperti yang diperlihatkan oleh siswa yang mengerjakan tugas yang diberikan sampai selesai walaupun dirasa sulit. Selanjutnya, pada indikator tidak meninggalkan tugas yang belum selesai memiliki persentase skor indikator sebesar $73,7 \%$. Hal ini diperlihatkan oleh siswa yang dapat menuntaskan tugasnya tanpa ada nomor yang dilewatkan dalam tugas tersebut. Sedangkan pada indikator terakhir yaitu tidak mudah menyerah dengan tugas merupakan indikator dengan persentase skor indikator sebesar 70,9 
\%. Hal ini diperlihatkan oleh siswa yang terus berusaha mengerjakan dan menyelesaikan tugasnya walaupun tidak dimengerti.

Berdasarkan pengujian hipotesis yang dilakukan, bahwa terdapat hubungan positif antara ketekunan (persistence) dengan hasil belajar biologi. Hal ini menunjukkan semakin tinggi ketekunan (persistence) yang dimiliki siswa maka semakin tinggi pula hasil belajar biologi. Begitu pula sebaliknya, semakin rendah ketekunan (persistence) yang dimiliki siswa maka semakin rendah pula hasil belajar biologi.

Seperti yang dikemukakan sebelumnya bahwa hasil belajar dapat dipengaruhi oleh ketekunan (persistence) siswa. Artinya jika ketekunan (persistence) ditingkatkan maka hasil belajar siswa juga meningkat. Hal ini juga berkaitan dengan hasil penelitian yang menyatakan bahwa mahasiswa yang memiliki komitmen tinggi untuk mendapatkan nilai yang baik cenderung memiliki tingkat ketekunan (persistence) yang tinggi pula (Cofer dan Summers, 2000). Namun dalam penelitian ini adalah siswa.

Hasil pengujian hipotesis menunjukkan bahwa ketekunan (persistence) memberikan kontribusi terhadap hasil belajar biologi siswa sebesar 75,69\% sedangkan $24,31 \%$ disebabkan oleh faktor lainnya. Faktor internal yakni minat, gaya belajar, intelejensi, konsep diri, serta arahan (direction) dan intensitas (intensity) yang merupakan elemen lain pembangun motivasi. Faktor eksternal yakni lingkungan belajar, keluarga, dan model pembelajaran.

\section{KESIMPULAN}

Berdasarkan hasil penelitian yang diperoleh, maka dapat disimpulkan bahwa terdapat hubungan positif antara ketekunan (persistence) dengan hasil belajar biologi siswa. Artinya makin tinggi tingkat ketekunan (persistence) maka makin tinggi pula hasil belajarnya. Apabila seseorang ingin meningkatkan hasil belajar biologi siswa, maka ketekunan (persistence) juga perlu diperkuat.

\section{DAFTAR PUSTAKA}

Cofer, J., dan Summers, P. (2000). Within-year persistence of students at twoyear colleges. Community College Journal of Research and Practice, 24, 785-807.

Dimyati \& Mudjiono. (2006). Belajar dan Pembelajaran. Jakarta: Rineka Cipta.

Ishler, Jennifer L. Crissman dan M. Lee Upcraft, The Keys to First-Year Student Persistence Chapter Two

Ivancevich, Konopaske, \& Matteson. (2007). Organizational Behavior and Management Eight Edition. New York: McGraw Hill.

Odum, E.P. (1993). Dasar-Dasar Ekologi Edisi Ketiga. Yogyakarta: Gadjah Mada University Press.

Schermerhorn, John R., James G. Hunt, \& Richard N. Osborn. (2011). Organizational Behaviour 10/E. USA: John Willey and Sons.

Sudjana, Nana. (2012). Penilaian Hasil Proses Belajar Mengajar. Bandung: Remaja Rosdakarya. 